\title{
ECOLOGICAL RISKS AND BENEFITS OF TRANSGENIC PLANTS
}

\author{
G.L. LÖVEI
}

\author{
Department of Crop Protection, Danish Institute of Agricultural Sciences, \\ Flakkebjerg Research Centre, DK-4200 Slagelse, Denmark \\ gabor.lovei@agrsci.dk
}

\begin{abstract}
The spread of commercial growing of transgenic crops has been very rapid, with such crops being grown on 44.2 million ha in 13 countries in 2000. Most currently grown transgenic plants are either herbicide or insect resistant, but research into other possibilities is intense. There are potentially significant environmental effects of this technology, as well as sharply conflicting claims about its overall impact. Among perceived risks, this review concentrates on the possibility of damaging ecosystem services (biological control, pollination, decomposition and soil fertility maintenance) and effects on biodiversity. Among the benefits, lower environmental contamination by fewer pesticide applications, less soil erosion due to less frequent agricultural operations and lower pressure on land resources due to increased yield, are listed. Both potential risks and benefits need careful documentation and validation for an appropriate assessment of the total ecological effects of this technology.

Keywords: transgenic plants, environmental risks, environmental benefits, ecosystem services, biodiversity, risk assessment.
\end{abstract}

\section{INTRODUCTION}

There is intense public interest accompanying the technology of genetic manipulations. Possibly not since nuclear physics produced the atomic bomb has an area of science fallen under such a sharp searching light by society. Different groups of the society are active in the field, spending an enormous amount of energy in different activities according to their roles, aims and perceptions. Much of this energy, however, goes up in heat; much less light has been generated. When attempting to add to the already profuse (but often data-poor, see Domingo 2000) literature related to the topic of transgenic organisms, it may be useful to precisely determine the scope of this review. Several important aspects of the effects of transgenic plants have been discussed and studied. An important consideration is ethical: do we have the right, or are we 'doing the proper thing' when engaged in genetic manipulations (Carr \& Levidow 1997)? The technology should also be evaluated in economic terms: are there real benefits from using this technology? There are concerns relating to the safety of transgenic food for human consumption (Domingo 2000; Ewen \& Pusztai 1999). Gene spread and resistance management are also major concerns (Gould 1998). These are important aspects of the topic, but lie outside the scope of the current review. This review only discusses potential risks and benefits of transgenic plants that can affect ecosystem services.

\section{THE CURRENT SITUATION WITH FIELD-GROWN TRANSGENIC} CROPS

The first transgenic crops were commercially planted in 1995. By 2000, a total of 44.2 million ha of transgenic plants were grown in 13 countries (James 2001). While this is only an $11 \%$ increase over the area in 1999 (much smaller than in earlier years), the spread of this technology has so far been very rapid. In 2000, the majority (84\%) of 
this increase occurred in the developing countries. World-wide, most transgenic crops are grown in developed countries (76\% of total area) and $24 \%$ in developing countries. Four countries, the USA, Argentina, Canada and China, grew 99\% of the global total of transgenic crops in 2000.

Most of this area is divided among four crops, soybean (58\%), maize (23\%), cotton $(12 \%)$ and oilseed rape (7\%). The area devoted to transgenic soybean and cotton increased since 1999, but that of maize and oilseed rape decreased (James 2001).

While a wide array of traits has been inserted into many species of plants, there are only a few in commercial cultivation, mostly herbicide resistance and insect resistance. Seventy-four percent of all transgenic crops in 2000 were herbicide resistant, $19 \%$ insect tolerant and a further $7 \%$ contained both these traits. Herbicide resistant soybean was the most widely planted transgenic crop $(59 \%$ of the global area devoted to transgenic crops), with insect-resistant maize a distant second (15\% of global area). Since 1999, the area devoted to herbicide tolerant plants has increased, while that of insect-resistant (Bt-) crops has decreased. The global share of transgenic crops is already considerable; $36 \%$ of all soybean, $16 \%$ of cotton, $11 \%$ of oilseed rape and $7 \%$ of maize was transgenic in 2000 (James 2001).

The regulations required for commercialisation and field growing of transgenic plants are diverse; in many countries they do not even exist. The latest directive of the European Union requires an environmental impact assessment and post-release monitoring, but specifies no methods. Generally, there is a lack of precise, justified legal framework that hinders assessment, potential commercial application and evaluation of this technology. This is not surprising, given the novelty of transgenic plants, and the state of research into their environmental effects. When the industry developing transgenic plants has been required to assess the potential environmental consequences of their products, the results have not been impressive (Purrington \& Bergelson 1995). There is clearly a need for a conceptual framework and more involvement of ecologists.

\section{AN ECOLOGICAL FRAMEWORK FOR ENVIRONMENTAL RISK} ASSESSMENT

We should not forget that agricultural fields are also part of the "ecological theatre" in which the "evolutionary play" (sensu Hutchinson 1965) is continuously being played. When transgenic plants are planted in the field, they will inevitably come into contact with many other species that together perform several ecological processes operating in agricultural fields. Listed below are a few significant "actors" in this "ecological theatre" that the transgenic plant will come into "ecological contact" with.

- Other plants, whether conspecifics or individuals of other species. This creates the question of invasiveness and gene spread.

- Herbivores that feed on plants above or below ground. The effects on non-target herbivores (and biodiversity) must be considered.

- Natural enemies of these organisms. What are the consequences for natural pest control?

- Pollinators that visit their flowers. What are the potential consequences for pollinating insects?

- Symbionts that live in the root zone, such as mycorrhizae or nitrogen-fixing bacteria.

- Detritivores and decomposers that feed on dead plant parts. How does this affect the soil ecological processes maintaining soil fertility, nutrient cycling and plant growth? Gene escape/invasiveness

Gene escape has been recognised as a potentially significant hazard (Wolfenbarger \& Phifer 2000). For many crops, outcrossing and hybridisation with wild relatives is possible (Elstrand et al. 1999). The ecological consequences of this could be serious if the new trait changes fitness parameters or invasiveness of the modified plants.

Invasiveness is recognised as a major threat in New Zealand, but invasions are also a global concern (Vitousek et al. 1997a; Lövei 1997). Data related to fitness or invasiveness 
of genetically modified plants are scarce. Stewart et al. (1997) found that oilseed rape containing the $B t$-toxin gene acquires a fitness advantage under insect herbivory. In a long-term study of survival in the wild and invasiveness of herbicide-resistant crop plants in different area of the British Isles, no genetically modified plant line survived longer than 4 years when planted in natural habitats (Crawley et al. 2001).

However, invasion success is scale-related, and it is rather difficult to predict the consequences of wide-scale planting of transgenic crops from limited-scale studies.

\section{Effects on non-target organisms}

Phytophagous organisms that were not targeted may still be affected by insect-resistant plants. For example, transgenic maize pollen, deposited on milkweed leaves could cause larval mortality of the monarch butterfly (Danais plexippus) (Losey et al. 1999), which is a species of important nature conservation focus in the U.S.A. This study spawned a number of others, indicating that natural pollen concentrations can still cause significant mortality (Hansen Jesse \& Obrycki 2000). Not all butterfly species seem to be under such risk. Larvae of the black swallowtail (Papilio polyxenes) are not sensitive to transgenic maize pollen (Wraight et al. 2000).

\section{Effects on natural enemies}

Insect-resistant plants are aimed at reducing the densities of certain phytophagous insects. These insects, however, also serve as prey for a range of natural enemies. An important potential effect of transgenic plants is the consequences of changing the occurrence and density of prey for natural enemies. If the density of prey is reduced, a direct flow-on effect could be a reduced density of their natural enemies. Transgenic potato controlling the Colorado potato beetle is probably responsible for a documented decrease of its specialist predatory ground beetle (Riddick et al. 1998).

Predatory and parasitoid insects are also sensitive to prey quality, and prey quality can be influenced by host plants, giving rise to tri-trophic interactions (Price et al. 1980). Several such examples have been found using transgenic plants or their experimental equivalents. For example, the parasitoid wasp Eulophus pennicornis had reduced parasitisation on tomato fruitworm (Lacanobia oleracea) hosts from plants with the cowpea trypsin inhibitor (Bell et al. 2001). Parasitoids can also react at a behavioural level to a host originating on transgenic plants (Schuler et al.1999).

Adults of the coccinellid A. bipunctata, when fed on aphids raised on transgenic potato (expressing the snowdrop lectin), were negatively affected. Adult female (but not male) longevity was reduced, egg laying and egg viability decreased (Birch et al. 1999). Interestingly, larvae of the same coccinellid did not seem to suffer the same consequences (Down et al. 2000).

In experiments conducted in New Zealand, Jørgensen \& Lövei (1999) found that adult ground beetles consumed less of their caterpillar prey when this prey was raised on proteinase inhibitor-containing diet vs normal diet. This effect persisted longer than the actual exposure to the manipulated prey and was age-dependent (Jørgensen \& Lövei 1999). Proteinase inhibitors seem to affect herbivore suitability as prey for this predator. Effects on pollinators

Plants that are pollinated by animals provide more than $25 \%$ of the world's food. Pollinating organisms in the temperate regions are mostly insects, namely bees and wasps (Buchmann \& Nabham 1996). They can be agents of pollen spread and exposed to any transgenic product that is expressed in pollen or nectar. Bees and bumble bees can be affected by transgenic products (Malone et al. 2001) and their systematic study needs to be incorporated into the environmental risk assessment of transgenic plants to make sure that this essential ecosystem service is not damaged (Lövei et al 2001).

\section{Effects on soil organisms and decomposers}

In root exudates of transgenic Bt-maize, the Bt-toxin was detected at concentrations that can kill insects (Saxena et al. 2000). The long-term consequences of this are not yet known. The study of soil organisms and processes is generally less advanced, reflecting the relative emphasis on above vs below-ground ecological processes (Brown \& Gange 
1990). In one of the most detailed studies published to date, Griffiths et al. (2000) found transient effects and significant changes in soil protozoan populations in soil under genetically engineered potato lines. As soil fertility maintenance is a biological process, tests of the effects of GM plants on soil processes are very important.

Many of these actors participate in ecological processes that are useful and necessary for agricultural production. These processes are termed 'ecosystem services' (Costanza et al. 1997). Until very recently an unappreciated 'endless resource', the global monetary value of these ecosystem services was estimated to surpass the combined Gross Domestic Product of the Earth's nations (Costanza et al. 1997).

I suggest that this framework of 'ecosystem services' would be useful in order to conceptualise the environmental risk assessment of transgenic plants.

Effects on biodiversity

Intensive agriculture, especially in the Northern Hemisphere, is a significant environmental management factor, and much of those countries' biological diversity is maintained in a cultivated landscape (Krebs et al. 1999). Altering the current management regime has potentially significant consequences for biological diversity in such countries.

Herbicide-resistant crops are expected to allow more efficient weed control. Concerns have been raised, especially in the United Kingdom, that this will have negative consequences for countryside biological diversity, with fewer surviving flowering plants to provide resources for organisms ranging from invertebrates to birds. The possible effects of such a scenario were approximated by modelling (Watkinson et al. 2000). These authors used a weed (Chenopodium album) and a songbird (skylark, Alauda arvensis) model in a landscape context to predict the effects of herbicide resistant sugarbeet on biological diversity in general. Their work points to potentially significant negative effects on seed-eating birds.

Similar concerns prompted the U.K. government to ban commercial growing of transgenic plants and initiate a 4-year farm-scale field trial to study what effect herbicideresistant transgenic plants will have on biodiversity (Firbank et al. 1999). Studies published so far on the effects of transgenic plants on agricultural biodiversity are rather imperfect (Hilbeck et al. 2000).

Agricultural biodiversity in New Zealand is generally low, and non-native species often form the majority of species found in cultivated habitats (Lövei 1991). There seems to be a limited interplay between native and non-native habitats in New Zealand. Current political thinking about biodiversity in New Zealand is concentrated on native organisms. Consequently, changes in cultivated land due to transgenic crops are expected to create problems for biodiversity only if invasiveness is affected.

\section{POTENTIAL ECOLOGICAL BENEFITS}

The evaluation of the environmental impact of transgenic organisms often centres on the risks attached to them. This is justified, as any new, large-scale technology does have risks and unforeseen consequences. However, a number of arguments have suggested a positive environmental impact from large-scale production of transgenic plants (Wolfenbarger \& Phifer 2000).

\section{Reduced environmental impact from pesticides}

Transgenic crops may decrease the use of environmentally harmful chemicals to control weeds and pests. This can happen in several different ways: certain pesticides are no longer used, the frequency of treatments is reduced, or the area treated is reduced (Wolfenbarger \& Phifer 2000).

For example, reduced frequency of treatments can bring a net decrease in pesticide pollution if paralleled with a decrease in the total amount of pesticide and herbicide used. Conflicting claims have been made about the effect of herbicide-tolerant crops in the U.S.A. (Ferber 1999; Carpenter \& Gianessi 2000). In the absence of published documentation where the assumptions and the validity of the arguments can be checked, no conclusions can be drawn (Wolfenbarger \& Phifer 2000). 


\section{Increased yield}

If crop yields increased, less cultivated area would be needed to produce the total amount of food required by people. This could result in a lower pressure on land not yet under cultivation and could allow more land to be left under protection. The potential environmental benefits of this type may be greatest in developing countries where most of the agricultural production increase was due to new areas taken into cultivation.

\section{Soil conservation}

Herbicide-tolerant crops may allow farmers to abandon the use of soil-incorporated pre-emergent herbicides. This shift to post-emergent weed control may increase the notill and conservation tillage practices, decreasing soil erosion, water loss, and increasing soil organic matter (Cannell \& Hawes 1994).

\section{Phytoremediation}

Genetically modified plants and micro-organisms can be used for in situ remediation of soil and water pollution. Transgenic plants can sequester heavy metals from soils (Gleba et al. 1999) or detoxify pollutants (Bizily et al. 2000). This has not yet been used widely, so its environmental impact has not been studied.

\section{CONCLUSION}

In conclusion, I suggest that the evaluation of the environmental effects of transgenic plants should include the study of beneficial ecological interactions. The significance of conceptualising this as the study on "ecosystem services" is more than semantic, as it links this question to one of the most important intellectual concepts of current ecology. This was borne by the necessity to convey the realisation that human impacts on ecosystems are global and profound (Vitousek et al. 1997b), and we need to use a unified conceptual approach to interpret them. If transgenic technology causes significant harm to these ecological services, we are heading the wrong way. There is too little resilience left in the natural ecosystems to absorb continued abuse.

However, assessing the impact of this technology does not have to be conducted with the mindset of "averting damage". The arguments regarding possible benefits of transgenic plants are plausible, but so far all of them are insufficiently documented (Wolfenbarger \& Phifer 2000). They need to be incorporated into the environmental impact of this technology. It is important to stress that the total environmental impact should be measured against current practice, and not against an idealised but non-existing agricultural cultivation system.

This may all seem entirely logical and unnecessary to emphasise. However, this view is not universal. The international think-tank CGIAR (Consultative Group on International Agricultural Research) lists the "environmental risk" of transgenic plants (Serageldin \& Persley 2000) in terms of:

- gene flow \& containment

- weediness

- $\quad$ trait effect

- $\quad$ genetic and phenotypic variability

- $\quad$ expression of genetic material from pathogens

- worker safety

From this seemingly exhaustive list (it even considers "worker safety"), all ecosystem services are missing. There is no mention of natural pest control, soil fertility maintenance, pollination or symbiosis as ecological functions that need to be considered when assessing the potential environmental impacts of this technology.

This may represent an exception, but the short-sightedness of this influential forum makes it important to spell out clearly that for GMO environmental risk assessment, an ecological approach is necessary. Further, ecology as a science has the conceptual framework and the methods that allow us to ask meaningful questions and produce answers pertinent to the environmental impact of gene technology. 


\section{ACKNOWLEDGEMENTS}

I thank M. McCambridge, B.P. Pedersen, I.W. Nielsen, U. Althoff, K. Frank, J. Lilholt, L. Pedersen and U. Sandberg for technical assistance; S. Bowra, E. Vincze and P. Brown for discussions; P. Brown and T. Glare for comments on the manuscript; and the NewZealand Plant Protection Society for inviting me to the conference and providing the opportunity to write this review. I acknowledge research funding by The Danish Research Agency (Denmark) and FRST (New Zealand).

\section{REFERENCES}

Bell, H.A.; Fitches, E.C.; Down, R.E.; Ford, L.; Marris, G.C.; Edwards, J.P.; Gatehouse, J.A.; Gatehouse, A.M.R. 2001: Effect of cowpea trypsin inhibitor (CpTI) on the growth and development of the tomato moth Lacanobia oleracae (Lepidoptera: Noctuidae) and on the success of the gregarious ectoparasitoid Eulophus pennicornis (Hymenoptera: Eulophidae). Pest Mgt Sci. 57: 57-65.

Birch, A.N.E.; Geoghean, I.E.; Majerus, M.E.N.; McNicol, J.W.; Hackett, C.A.; Gatehouse, A.M.R.; Gatehouse, J.A. 1999: Tri-trophic interactions involving pest aphid, predatory 2 -spot ladybirds and transgenic potatoes expressing snowdrop lectin for aphid resistance. Mol. Breed. 5: 75-83.

Bizily, S.P.; Rugh, C.L.; Meagher, R.B. 2000: Phytodetoxification of hazardous organomercurials by genetically engineered plants. Nat. Biotechnol. 18: 213- 217.

Brown, V.K.; Gange, A.C. 1990: Insect herbivory below ground. Adv. Ecol. Res. 20: 158 .

Buchmann, S.L.; Nabham,G.P. 1996: The forgotten pollinators. Island Press, Washington, D.C. 292 p.

Cannell, R.Q.; Hawes, J.D. 1994: Trends in tillage practices in relation to sustainable crop production with special reference to temperate climates. Soil Till. Res. 30: $245-282$.

Carpenter, J.; Gianessi, L. 2000: Herbicide use on Roundup ready crops. Science 287: 803-804.

Carr, S.; Levidow, L. 1997: How biotechnology regulation separates ethics form risk. Outlook on Agric. 26: 145-150.

Crawley, M.J.; Brown, S.L.; Hails, R.S.; Kohn, D.D.; Rees, M. 2001: Transgenic crops in natural habitats. Nature 409: 682-683.

Domingo, J.L. 2000: Health risks of GM foods: many opinions but few data. Science 288: $1748-1749$.

Down, R.E.; Ford, L.; Woodhouse, S.D.; Raemaekers, R.J.M.; Leitch, B.; Gatehouse, J.A.; Gatehouse, A.M.R. 2000: Snowdrop lectin (GNA) has no acute toxic effects on a beneficial insect predator, the 2-spot ladybird (Adalia bipunctata L.). J. Ins. Physiol. 46: 379-391.

Elstrand, N.C.; Prentice, H.C.; Hancock, J.F. 1999: Gene flow and introgression from domesticated plants into their wild relatives. Ann. Rev. Ecol. Syst. 30: 539-563.

Ewen, S.W.B.; Pusztai, A. 1999: Effects of diets containing genetically modified potatoes expressing Galanthus nivalis lectin on rat small intestine. Lancet 354: 1353-1354.

Ferber, D. 1999: GM crops in the cross hair. Science 286: 1662-1666.

Firbank, L.G.; Dewar, A.M.; Hill M.O.; May, M.J.; Perry, J.N.; Rothery, P.; Squire, G.R.; Woiwod, I.P. 1999: Farm-scale evaluation of GM crops explained. Nature 399: 727-728.

Gleba, D.; Borisjuk, N.V.; Borisjuk, L.G.; Kneer, R.; Poulev, A.; Sarzhinskaya, M.; Dushenkov. S.; Logendra, S.; Gleba, Y.Y.; Raskin, I. 1999: Use of plant roots for phytoremediation and molecular farming. Proc. Natl. Acad. Sci. U.S.A. 96: 5973 5977.

Gould, F. 1998: Sustainability of transgenic insecticidal cultivars: integrating pest genetics and ecology. Ann. Rev. Entomol. 43: 701-726. 
Griffiths, B.S.; Geoghean, I.E.; Robertson, W.M. 2000: Testing genetically engineered potato, producing the lectins GNA and ConA, on non-target soil organisms and processes. J. Appl. Ecol. 37: 159-170.

Hansen Jesse, L.C.; Obrycki, J.J. 2000: Field deposition of Bt transgenic corn pollen: lethal effects on the monarch butterfly. Oecologia 125: 241-248.

Hilbeck, A.; Meier, M.S.; Raps, A. 2000: Review on non-target organisms and Bt-plants. Ecostrat Gmbh, Zurich. 77 p.

Hutchinson, G.E. 1965: The ecological theatre and the evolutionary play. Yale Univ. Press, New Haven, U.S.A.

James, C. 2001: Global review of commercialized transgenic crops: 2000. ISAAA Briefs No. 21: Preview. ISAAA, Ithaca, NY.

Jørgensen, R.B.; Hauser, T.; Mikkelsen, T.R.; Østergård, H. 1996: Transfer of engineered genes from crop to wild plants. Trends Plant Sci. 1: 356-358.

Jørgensen, H.B.; Lövei, G.L. 1999: Tritrophic effects on predator feeding: consumption by the carabid Harpalus affinis of Heliothis armigera caterpillars fed on proteinaseinhibitor-containing diet. Entomol. Exp. Appl. 93: 113-116.

Krebs, J.R.; Wilson, J.D.; Bradbury, R.B.; Siriwardena, G.M. 1999: The second silent spring? Nature 400: 611-612.

Losey, J.E.; Raynor, L.S.; Carter, M.E. 1999: Transgenic pollen harms monarch larvae. Nature 399: 214.

Lövei, G.L. 1991: The ground-dwelling predatory fauna in an organic and an abandoned kiwifruit orchard. In: Popay, L. ed. Proceedings of the N.Z. Inst. Agric. Sci. \& N.Z.Hort. So.c Symp. on Sustainable Agriculture and Organic Food Production. Pp. 9-14.

Lövei, G.L. 1997: Global change through invasion. Nature 388: 627-628.

Lövei, G.L.; Felkl, G.; Broodsgaard, H.B.; Hansen L.M. 2001: Environmental risks of insect -tolerant transgenic plants. 18th Danish Plant Prot. Conf., DJF Rapport nr. 41: 171-176.

Malone, L.A.; Burgess, E.P.J.; Gatehouse, H.S.; Voisey, C.R.; Tregida, E.L.; Philip, B.A. 2001: Effects of ingestion of a Bacillus thuringiensis toxin and a trypsin inhibitor on honey bee flight activity and longevity. Apidologie 32: 57-68.

Purrington, C.B.; Bergelson, J. 1995: Assessing weediness of trangenic crops: industry plays plant ecologist. Trends Ecol. Evol. 10: 340-342.

Price, P.W.; Bouton, C.E.; Gross, P.; Bruce, A.M.; Thompson, J.N.; Weis, A.E. 1980: Interactions among three trophic levels: influence of plants on interactions between insect herbivores and natural enemies. Ann. Rev. Entomol. 11: 41-65.

Riddick, E.W.; Dively, G.; Barbosa, P. 1998: Effect of a seed-mix deployment of Cry3Atransgenic and nontransgenic potato on the abundance of Lebia grandis (Coleoptera : Carabidae) and Coleomegilla maculata (Coleoptera : Coccinellidae). Annals Entomol. Soc. America 91: 647 - 653.

Saxena, D.; Flores, S.; Stotzky, G. 2000: Insecticidal toxin in root exudates from Bt corn. Nature 402: 480.

Schuler, T.H.; Potting, R.P.J.; Denholm, I.; Poppy, G.M. 1999: Parasitoid behaviour and Bt plants. Nature 400: 825-826.

Serageldin, I.; Persley, G.J. 2000: Promethean science: agricultural biotechnology, the environment, and the poor. Consultative Group on International Agricultural Research, Washington, D.C. 41 p.

Stewart, C.N. jr.; All, J.N.; Raymer, P.L.; Ramachadran, S. 1997: Increased fitness of transgenic insecticidal rapeseed under insect selection pressure. Mol. Ecol. 6: 773779.

Vitousek, P.M.; D’Antonio, C.M.; Loope, L.L.; Rejmanek, M.; Westbrooks, R. 1997a: Introduced species: a significant component of human-caused global change. N.Z. J. Ecol. 21: 1-16. 
Vitousek, P.M.; Mooney, H.A.; Lubchenco, J.; Melillo, J.M. 1997b: Human domination of Earth's ecosystems. Science 277: 494-499.

Watkinson, A.R.; Freckleton, R.P.; Robinson, R.A.; Sutherland, W.J. 2000: Predictions of biodiversity response to genetically modified herbicide-tolerant crops. Science 289: 1554-1557.

Wolfenbarger, L.L.; Phifer, P.R. 2000: The ecological risks and benefits of genetically engineered plants. Science 290: 2088-2093.

Wraight, C.L.; Zangerl, A.R.; Carroll, M.J.; Berenbaum, M.R. 2000: Absence of toxicity of Bacillus thuringiensis pollen to black swallowtails under field conditions. Proc. Natl. Acad. Sci. U.S.A. 97: 7700-7703. 